\title{
Alternative device for ANAMMOX/denitrification rate assessment using manometric method
}

\author{
Łukasz Kokurewicz ${ }^{1}$, and Mateusz Muszyński-Huhajło ${ }^{1, *}$ \\ ${ }^{1}$ Faculty of Environmental Engineering, Wroclaw University of Science and Technology, \\ Place Grunwaldzki 9, 50-377 Wroclaw, Poland
}

\begin{abstract}
Anammox and denitrification processes play important role in nitrogen removal in wastewater treatment. In final stage of nitrogen compounds metabolism nitrogen gas is produced and released to atmosphere. Process rates can be estimated based on amount of produced nitrogen, but this kind of procedure requires special equipment that may be a significant obstacle in bringing this type of tests to common practice in wastewater treatment plants. A low-cost device was constructed to verify if such installation may be a reliable alternative for expensive commercially available products (e.g. OxiTop ${ }^{\circledR}$ system). Values of Specific Anammox Activity measured in different temperatures by constructed device and OxiTop ${ }^{\circledR}$ system were consistent in $86.3 \%$. Average gas production based on pressure growth exceed $94.9 \%$ the values obtained by use of chemical analysis. Conducted tests confirmed that low-cost manometric device can be a useful tool in denitrification/Anammox sludge activity tests.
\end{abstract}

\section{Introduction}

Excess nitrogen loads directed with wastewater to lakes and rivers have always been an important issue for their water quality and aquatic biodiversity. Activated sludge process, known since the beginning of $20^{\text {th }}$ century, in fact, was not able to solve this problem until the 50s, when Wuhrmann suggested oxic-anoxic (OA) reactor configuration to allow denitrification of nitrate previously produced in oxic reactor. However, the real breakthrough for biological nitrogen removal was noticed in 1962 when Ludzack and Ettinger developed an anoxic-oxic (AO) process. Reduction of external organic carbon requirement was a real boost for denitrification efficiency and allowed to meet more and more strict effluent quality standards. Efficient and sustainable N-removal has become standard on wastewater treatment plants (WWTPs) worldwide [1].

Much later, in 90s, another crucial for nitrogen removal discovery has been made when Mulder et al. [2] reported identification of new autotrophic microorganisms group able to anaerobic ammonium oxidation using nitrite, called Anammox (acronym for ANaerobic AMMonium OXidation). From this moment, process was successfully introduced in sidestream installations for ammonia-rich streams treatment, with over 100 full-scale implementations by 2014 [3]. Nowadays, implementation of this process for the municipal

${ }^{*}$ Corresponding author: mateusz.muszynski-huhajlo@pwr.edu.pl 
wastewater treatment (called as mainstream Anammox) is supposed to be the major step for energy self-sufficient and highly effective WWTPs [4].

Important role and increasing popularity of mentioned processes creates need for appropriate methods of process rate and efficiency evaluation, not only for research purposes, but also as self-control tools on full-scale plants. Due to dinitrogen gas production, as product of these reactions, manometric method is one of possible ways to evaluate their efficiency. In this paper, development and validation of a new, self-made installation for denitrification/Anammox process rate measurements is presented as a useful alternative for commercially available products.

\subsection{Denitrification and Anammox -key elements in N-cycle}

\subsubsection{Denitrification}

Due to its prevalence in wastewater treatment systems, in this study, only heterotrophic denitrification will be considered. It's biochemical process of nitrite and/or nitrate reduction under anoxic conditions with limited dissolved oxygen availability due to their facultative anoxic/aerobic metabolism. Denitrifying bacteria, which turn $\mathrm{NO}_{\mathrm{x}}-\mathrm{N}$ back into nitrogen gas for energy generation, play crucial role in natural nitrogen cycle and wastewater treatment. As a final stage of N-removal, denitrification is often limiting due to insufficient organic matter as an electron donor for full reduction of nitrogen oxides load. Metabolic pathway of this process in conventional activated sludge systems with full nitrification can be described by Eq. 1. As presented below, reaction increases the environment alkalinity due to the production of hydroxide ions [5].

$$
\mathrm{NO}_{3}^{-}+1.25 \mathrm{CH}_{2} \mathrm{O} \rightarrow 0.5 \mathrm{~N}_{2}+\mathrm{OH}+0.75 \mathrm{H}_{2}+1.25 \mathrm{CO}_{2}
$$

\subsubsection{Anammox}

Discovery of anaerobic ammonium oxidation, performed by a group of bacteria with unique metabolism, shed new light on biological nitrogen cycle [6]. As it turned out, Anammox microorganisms are responsible for $30-70 \%$ of fixed nitrogen removal from marine environment and have ability to survive in a wide range of environments, also including activated sludge [7, 8]. In general, Anammox is an anaerobic multi-stage process: nitrite $\left(\mathrm{NO}_{2}^{-}\right)$is reduced to nitric oxide $(\mathrm{NO})$ that reacts with ammonium $\left(\mathrm{NH}_{4}^{+}\right)$producing hydrazine $\left(\mathrm{N}_{2} \mathrm{H}_{4}\right)$, which is oxidized to nitrogen gas $\left(\mathrm{N}_{2}\right)$ [9]. Reaction stoichiometry is given by Eq. 2 [10]:

$$
\begin{array}{r}
\mathrm{NH}_{4}^{+}+1.32 \mathrm{NO}_{2}^{-}+0.066 \mathrm{HCO}_{3}^{-}+0.13 \mathrm{H}^{+} \rightarrow \\
1.02 \mathrm{~N}_{2}+0.066 \mathrm{CH}_{2} \mathrm{O}_{0.5} \mathrm{~N}_{0.15}+0.26 \mathrm{NO}_{3}^{-}+2.03 \mathrm{H}_{2} \mathrm{O}
\end{array}
$$

As mentioned above, Anammox process requires suitable nitrite/ammonium ratio in treated medium, usually achieved by combining Anammox with partial nitritation process (PN). Necessity of only partial oxidation of ammonium in this processes reduces net oxygen required for nitrogen removal to $1.71 \mathrm{mg} \mathrm{O} / \mathrm{mg} \mathrm{NH}_{4}{ }^{+} \mathrm{N}$ converted into gas if influent biodegradable organic matter is used to denitrify residual $\mathrm{NO}_{\mathrm{x}}-\mathrm{N}$ [11]. Autotrophic metabolism of Anammox bacteria keeps this reaction independent from organic matter availability, as the inorganic carbon is used for biomass yield. 


\subsection{Manometric measurements technique}

Rates of biological processes can be easily estimated based on their substrate utilization and products formation change in time. In some cases, such as denitrification and Anammox, when main product is a gas with low solubility, an indirect measurement of pressure growth due to gas production in air-tight vessel can provide information about process dynamics. Nitrogen gas, as main product of both reactions considered in this study, and its solubility change due to pressure growth can be considered as irrelevant in pressure range achieved in this type of tests. Otherwise than nitrogen, carbon dioxide has much higher solubility [12] and its production must be included in the gas production calculations or an $\mathrm{CO}_{2}$ adsorbent should be used during denitrification rate measurements.

Described method has been proven to be adequate for activity and inhibition tests in number of studies, both for Anammox [13-17], as for denitrification [18]. Contrary to traditional measurements of bioprocess activity based on product/substrate profiles using chemical analysis, manometric method requires an air-tight vessel connected to a manometer for overpressure recording. Also, due to oxygen inhibition of described processes, an installation for flushing the sample and headspace with inert gas is needed. These facts make this type of measurements impossible without proper equipment. One of the most popular commercial devices used for this purpose is OxiTop ${ }^{\circledR}$ Control System (WTW, Germany) [13-17]. However, such specialized equipment can be considered as expensive a major obstacle for wide use of this method.

This paper presents a description of a self-made apparatus for manometric tests for denitrification/Anammox process rates assessment, including procedure description and validation test for mentioned installation based on comparison with analytical methods and parallel test performed in and OxiTop ${ }^{\circledR}$ device.

\section{Materials and methods}

\subsection{Nitrogen gas production calculations based on recorded pressure change}

Amount of nitrogen gas $\left(\mathrm{N}_{2}\right)$ produced during the test is calculated according to Clapeyron's ideal gas law, formulated in 1834 and describing relation between pressure, temperature and amount of gas in constant volume. Based on this relation, recorded pressure change $(\Delta p, \mathrm{~Pa})$ can be used for calculation of mass of produced gas $(\Delta m, \mathrm{~g})$ assuming that nitrogen molar volume equals $22.4 \mathrm{dm}^{3} / \mathrm{mol}$ and its density $\left(\rho_{N_{2}}\right)$ equals $1.25 \mathrm{~g} / \mathrm{dm}^{3}$. A following equation (3) can be given:

$$
\Delta m=\frac{\Delta p V_{p}}{R T} \cdot 22.4 \cdot \rho_{N_{2}}
$$

where $V_{p}$ - gas volume $\left[\mathrm{m}^{3}\right], \mathrm{R}$ - gas constant $\left[\frac{\mathrm{J}}{\mathrm{mol} \cdot \mathrm{K}}\right]$ and $\mathrm{T}$ is temperature $[\mathrm{K}]$.

\subsection{Measuring apparatus}

\subsubsection{Self-made reactor}

A plastic vessel with volume of $390 \mathrm{~cm}^{3}$ has been used for constructing an air-tight reactor for denitrification/Anammox batch test. The reactor is equipped with a diffusor for flushing the sludge sample with an inert gas, temperature sensor and 4 valves for sample collection, manometer connection and substrate dosing. Sample mixing is provided by 
using a magnetic stirrer. Gas headspace is connected through one of the valves with a manometer (Abatronic AB-8897) with data recording. Apparatus used during the tests has been presented in Fig. 1.

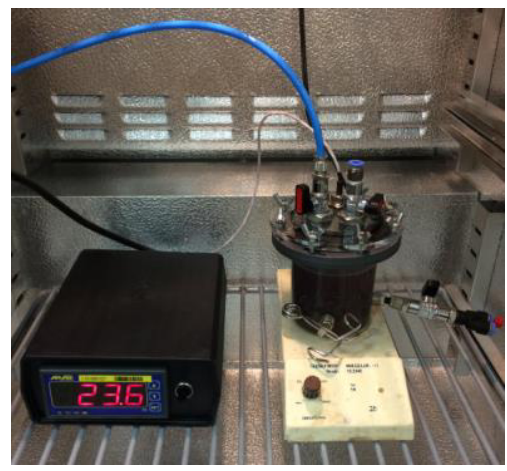

Fig. 1. Measuring apparatus on a magnetic stirrer (manometer not shown).

\subsubsection{OxiTop ${ }^{\circledR}$}

A WTW's OxiTop ${ }^{\circledR}$ Control System was used to perform a parallel manometric test on the same Anammox sludge sample as in the self-made reactor. Device consisted of $650 \mathrm{~cm}^{3}$ glass vessel with OxiTop ${ }^{\circledR}$ head for pressure control. All procedures, substrates and data interpretation was similar to one used in test performed in an alternative device described in this paper.

\subsection{Samples and substrate source}

Anammox sludge for performed batch tests was taken from a pilot-scale installation with a two-stage PN-Anammox in SBR with operational volume of $100 \mathrm{dm}^{3}$ treating real reject water from sludge dewatering at one of Polish WWTPs with capacity over 500000 p.e. Anammox process was stably operated for over 6 months before sludge samples were collected for batch tests presented in this study. Process was operated at temperature $23^{\circ} \mathrm{C}$ and $\mathrm{pH}=7.0$. For batch tests, a synthetic medium was used containing: $1300 \mathrm{mg} \mathrm{NH}{ }^{+}-\mathrm{N} / \mathrm{dm}^{3}, 1500 \mathrm{mg} \mathrm{NO}{ }_{2}^{-}-\mathrm{N} / \mathrm{dm}^{3}$ and $\mathrm{NaCO}_{3}$ to provide inorganic carbon source.

\subsection{Test procedure}

Sludge samples, taken from the SBR, were placed in an incubator set at temperature desired for the test. After the temperature stabilization, sample was put into batch test reactor. For performed tests headspace-to-sample volume ratio was set at about 1:3, resulting $290 \mathrm{~cm}^{3}$ of sample of mixed liquor for single test. Sample concentration of nitrogen compounds was identified $\left(\mathrm{NH}_{4}{ }^{+}, \mathrm{NO}_{2}{ }^{-}, \mathrm{NO}_{3}{ }^{-}\right)$and, if required, sample was flushed with SBR effluent to remove present substrates which may cause gas production in the phase of gas-liquid equilibrium stabilization. To sustain anaerobic/anoxic conditions, sample was purged with nitrogen gas for 20-40 minutes with periodical dissolved oxygen and $\mathrm{pH}$ was adjusted to about 7.0 by dosing a $5 \% \mathrm{H}_{2} \mathrm{SO}_{4}$ solution if needed. After that, reactor cover was sealed and headspace over the sample was purged for another 5 min to secure oxygen removal from the installation. When nitrogen flow was cut off, pressure was levelled with atmosphere and a 60-min phase of gas-liquid equilibrium stabilization begun, 
when sample was constantly mixed (see more in section 3.1.2). After this period, substrate was added to achieve initial concentrations of ammonium and nitrite at 60 and $50 \mathrm{mg} \mathrm{N} / \mathrm{dm}^{3}$, respectively. During substrate addition, headspace was also purged with $\mathrm{N}_{2}$ to prevent any oxygen penetration into the vessel. After few minutes of mixing, a sample of mixed liquor was taken to measure initial test concentrations and pressure recording started. Test was conducted until pressure growth has slowed, typically for 60-120 minutes, depending on temperature and initial substrate concentrations.

\subsection{Analytical methods}

All samples were filtered with syringe filters, pore size $1.2 \mu \mathrm{m}$ and after that ammonium, nitrite and nitrate nitrogen concentrations were measured using Hach Lange's photometric cuvette tests: LCK303 $\left(2-47 \mathrm{mg} \mathrm{NH}{ }_{4}^{+}-\mathrm{N} / \mathrm{dm}^{3}\right)$, LCK342 (range 0,6 - $6 \mathrm{mg} \mathrm{NO}{ }_{2}^{-}-\mathrm{N} / \mathrm{dm}^{3}$ ) and LCK340 (range $5-35 \mathrm{mg} \mathrm{NO}{ }_{3}^{-} \mathrm{N} / \mathrm{dm}^{3}$ ) and a DR3900 spectrophotometer. Total suspended solids (TSS) and volatile suspended solids (VSS) concentrations were determined using direct weight method according to Standard Methods guideline.

\section{Results and discussion}

\subsection{Apparatus and test procedure validation}

\subsubsection{Batch reactor air-tightness tests}

First step to verify if constructed installation can be used for manometric tests was to check its air-tightness by measuring potential pressure loss in time. To reduce impact of gas solubility in water, vessel was filled with a saturated saline solution $(\sim 26,5 \% \mathrm{NaCl})$. Firstly, low-pressure tests were conducted: overpressure in the vessel was kept at level around 3-5 $\mathrm{kPa}$ for 24 hours. No relevant pressure change was noticed that indicates proper air-tightness of the reactor.

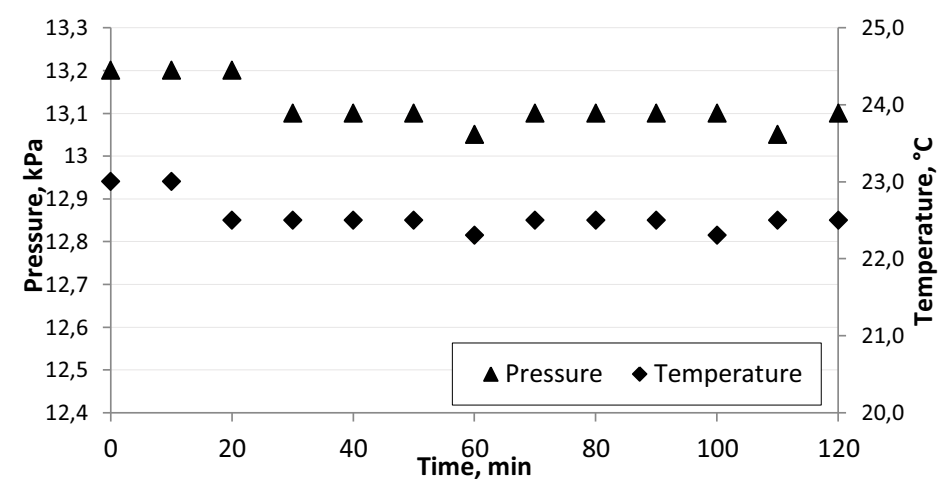

Fig. 2. Short-term apparatus air-tightness verification test results on saturated saline water $(\mathrm{NaCl})$.

Range of pressure expected during manometric tests is about 5-20 kPa and takes around 2 hours which is strictly connected on the initial substrate concentration and process rate. Next step was to verify pressure change at higher pressure levels $(\sim 15 \mathrm{kPa})$ in a short-term ( 2 hour) tests. Results of long and short-term test, such as one presented in Figure 2, clearly indicates that constructed vessel provide sufficient tightness to conduct manometric tests. 
Observed pressure fluctuation was strictly connected with temperature change of gas in the space over liquid phase.

\subsubsection{Achieving liquid-gas phase balance}

Due to nitrogen gas flushing, it's necessary to restore gas-liquid balance between sludge sample and gas space in the vessel. Continuous mixing provides proper contact between these phases but dynamics of this process was unknown. To decide how much time is needed to establish such balance after 40 minutes of purging the sample with $\mathrm{N}_{2}$ a series of tests was conducted. Results are shown in Figure 3.

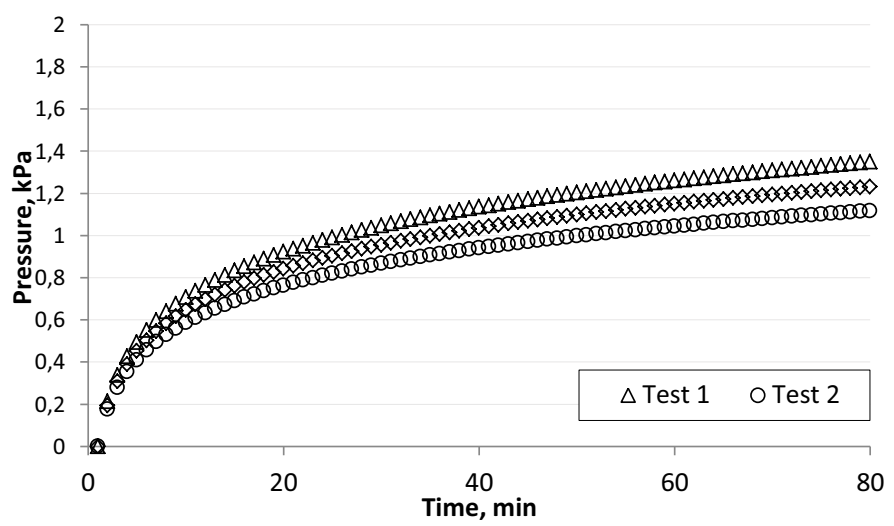

Fig. 3. Observed pressure change in headspace over a $\mathrm{N}_{2}$-purged sample.

It can be clearly noticed that, after more than 60 minutes from cutting the flow of $\mathrm{N}_{2}$, pressure growth slows down and further changes can be considered as insignificant for the final test results as average pressure growth in this period was equal $0.044 \mathrm{kPa} / \mathrm{min}$. Such pressure stabilization period was present in methodology of all conducted tests.

\subsection{Anammox process rate tests - Specific Anammox Activity (SAA)}

\subsubsection{Analytical methods vs produced nitrogen gas}

Sample collection after substrate dosing and at the end of each test allows to verify amount of produced nitrogen gas with $\mathrm{N}$-compounds left in the mixed liquor. $\mathrm{NH}_{4}^{+}-\mathrm{N}$, $\mathrm{NO}_{2}^{-}-\mathrm{N}$ and $\mathrm{NO}_{3}{ }^{-}-\mathrm{N}$ concentrations were measured in all samples to calculate $\mathrm{N}$ mass balance which was compared with the mass of nitrogen in the headspace calculated from the pressure growth during the test (see point 2.1). Summary of gained results is presented in Table 1.

For the first test (ANMX $1 *$ ), real effluent from PN reactor was used as a batch test substrate $\left(420 \mathrm{mg} \mathrm{NH}_{4}{ }^{+} \mathrm{N} / \mathrm{dm}^{3}\right.$ and $\left.533 \mathrm{mg} \mathrm{NO}_{2}{ }^{-}-\mathrm{N} / \mathrm{dm}^{3}\right)$. Relatively low concentration of substrates resulted in big volume of added solution, which might have caused problems with abnormal overpressure in the vessel causing its possible unsealing. Another fact is, that such volume of substrate solution might not been measured precisely affecting calculations and lowering volume of headspace in the vessel. Based on this experience, only synthetic medium was used in further tests (see section 2.3).

Other tests revealed a good correlation between produced gas and depletion of nitrogen mass in the mixed liquor in wide range of temperatures $\left(20-32^{\circ} \mathrm{C}\right)$ and maximal 
overpressure recorded during each test, equal to $7.3 \mathrm{kPa}, 4.35 \mathrm{kPa}$ and $9.37 \mathrm{kPa}$ for ANMX1, ANMX2 and ANMX3, respectively.

Table 1. Summary of results obtained in performed tests.

\begin{tabular}{|c|c|c|c|c|c|c|}
\hline \multirow{2}{*}{ Test no. } & \multirow{2}{*}{ Temp. } & \multicolumn{2}{|c|}{ Nitrogen production / loss } & \multicolumn{2}{|c|}{ SAA } & \multirow{2}{*}{$\begin{array}{c}\text { Percentage } \\
\text { ratio } \\
\text { manometric } \\
\text { analytical }\end{array}$} \\
\hline & & manometric & analytical & manometric & analytical & \\
\hline- & ${ }^{\circ} \mathrm{C}$ & $\mathrm{mg} \mathrm{N}$ & $\mathrm{mg} \mathrm{N}$ & \multicolumn{2}{|c|}{$\mathrm{g} \mathrm{N} \mathrm{gVSS}^{-1} \mathrm{day}^{-1}$} & $\%$ \\
\hline ANMX 1* & 25 & 9.4 & 12.8 & 0.352 & 0.480 & 73.4 \\
\hline ANMX 1 & 26 & 8.0 & 7.9 & 0.320 & 0.315 & 101.3 \\
\hline ANMX 2 & 20 & 5.5 & 5.6 & 0.185 & 0.189 & 98.2 \\
\hline ANMX 3 & 32 & 12.2 & 13.2 & 0.812 & 0.876 & 92.4 \\
\hline ANMX 4 & 23 & 6.6 & 7.5 & 0.471 & 0.537 & 88.0 \\
\hline
\end{tabular}

In Figure 4, typical pressure profile for performed manometric test is presented (ANMX1). It can be clearly noticed, that maximum process rate, observed as pressure growth due to gas production, was achieved between $5^{\text {th }}$ and $60^{\text {th }}$ minute of performed test when no substrate limiting occurred.

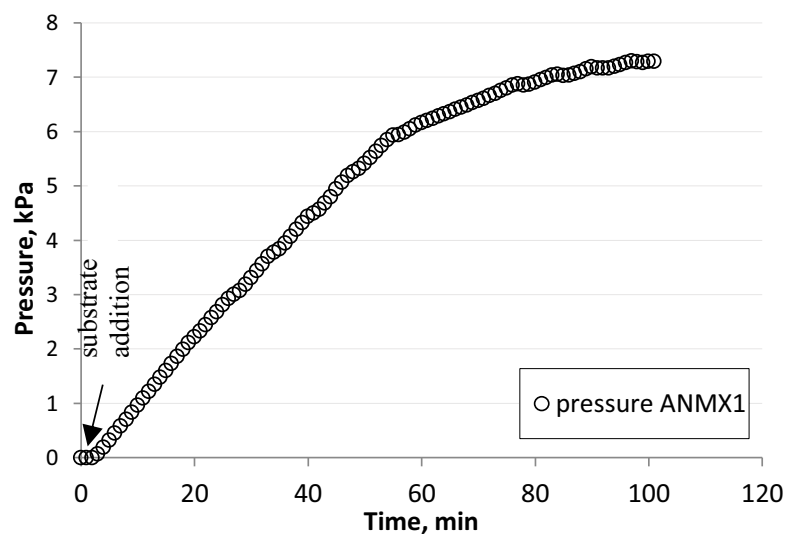

Fig. 4. Pressure profile during a manometric test (ANMX1).

\subsubsection{Alternative device vs OxiTop ${ }^{\circledR}$}

Good conformity of the manometric and analytical results suggests that calculated SAA rates are highly reliable. To verify that assumption, a parallel test performed in a OxiTop ${ }^{\circledR}$ device was performed on the same Anammox sludge sample as in alternative device. Results gained from OxiTop ${ }^{\circledR}$ revealed that SAA was $0.94 \mathrm{~g} \mathrm{~N} \cdot \mathrm{gVSS}^{-1}$ day $^{-1}$ for manometric calculations and $1.038 \mathrm{~g} \mathrm{~N} \cdot \mathrm{gVSS}^{-1}$ day $^{-1}$ for analytical results.

Considering commercially available equipment as more reliable than constructed one, SAA obtained in alternative device was equal to $86.3 \%$ and $84.4 \%$ of values from the OxiTop ${ }^{\circledR}$ test for manometric and analytical results, respectively. This fact indicates need of further development and improvement of the construction and methodology of alternative apparatus to improve results quality. 


\section{Conclusions}

- Manometric measurement technique is a very useful and reliable alternative for chemical tracking in case of denitrification/Anammox process rate. Lower number of samples than in analytical measurements and on-line control of gas production reduces required effort and provides a lot of useful information about process dynamics. Despite the obvious benefits of using this method, necessity of owning a specialized equipment may be an obstacle.

- A low-cost apparatus has been constructed as an alternative for currently available commercial products. Series of preliminary test has been conducted to verify airtightness of constructed installation achieving positive results. Construction can be used as a potential batch test reactor for manometric tests.

- Air-liquid phase balance after purging the mixed liquor sample must be re-established, due to significant pressure changes that may affect final test results. Conducted tests revealed 60 minutes of mixing in sealed vessel as sufficient period for minimalizing impact of this effect.

- High-strength synthetic medium was more suitable as a batch test substrate due to lower volume added to the vessel.

- Tests performed in constructed reactor have shown good accuracy of achieved results in comparison with chemical tracking. Average gas production based on pressure growth was equal to $94.9 \%$ in 4 successfully performed test (standard deviation: $5.1 \%$ ) in wide range of maximal recorded pressure and temperature of the test.

- SAA obtained in alternative device was equal to $86.3 \%$ and $84.4 \%$ of values from the OxiTop $^{\circledR}$ test for manometric and analytical results, respectively.

- Despite promising results of manometric and analytical calculations in tests performed in the self-made apparatus, further tests must be performed to investigate causes of observed differences in comparison with OxiTop ${ }^{\circledR}$ test result.

\section{References}

1. E. Klaczyński, P. Ratajczak, Wodociągi i Kanalizacja 5 (2013)

2. A. Mulder, A.A. Van De Graaf, L.A. Robertson, J.G. Kuenen, Fems Microbiol. Ecol. $16(1995)$

3. S. Lackner, E.M. Gilbert, S.E.Vlaeminck, A. Joss, H. Horn, M.C.M. Van Loosdrecht, Water Res. 55 (2014)

4. M.C.M. Van Loosdrecht, D. Brdjanovic, Science 344 (2014)

5. V. Matějů, S. Čižinská, J. Krejčí , T. Janoch, Enzyme Microb. Tech. 14 (1992)

6. M.M.M. Kuypers, G. Lavik, D. Woebken, M. Schmid, B.M. Fuchs, R. Amann, B.B. Jørgensen, M.S.M. Jetten, P. Natl. Acad. Sci. USA. 102 (2005)

7. A.H. Devol, Nature 422 (2003)

8. B. Fu, J. Liu, H. Yang, T.C. Hsu, B. He, M. Dai, S.J. Kao, M. Zhao, X.-H. Zhang, J. Geophys. Res-Oceans 120 (2015)

9. B. Kartal, W.J. Maalcke, N.M. De Almeida, I. Cirpus, J. Gloerich, W. Geerts, H.J.M. Op Den Camp, H.R. Harhangi, E.M. Janssen-Megens, K.-J. Francoijs, H.G. Stunnenberg, J.T. Keltjens, M.S.M. Jetten, M. Strous, Nature 479 (2011)

10. M. Strous, J.J. Heijnen, J.G. Kuenen, M.S.M. Jetten, Appl. Microbiol. Biot. 50 (1998)

11. G.T. Daigger, Water Environ. Res. 86 (2014)

12. N.I. Kolev, Multiphase Flow Dynamics 3: Turbulence, Gas Absorption and Release, Diesel Fuel Properties, (Springer, 2002) 
13. A. Dapena-Moraa, I. Fernándeza, J.L. Camposa, A. Mosquera-Corrala, R. Méndeza, M.S.M. Jettenb, Enzyme Microb. Tech. 40 (2007)

14. D. Scaglione, G. Buttiglieri, E. Ficara, S. Caffaz, C. Lubello, F. Malpei, Water Sci. Technol. 60 (2009)

15. E. Bettazzia, S. Caffazb, C. Vanninic, C. Lubelloa, Process Biochem. 45 (2010)

16. T. Lotti, W.R.L. Van Der Starc, R. Kleerebezema, C. Lubellob, M.C.M. Van Loosdrechta, Water Res. 46 (2012)

17. E.M. Gilbert, S. Agrawal, S.M. Karst, H. Horn, P.H. Nielsen, S. Lackner, Envir. Sci. Tech. 48 (2014)

18. M. Sánchez, A. Mosquera-Corral, R. Méndez, J.M. Lema, Bioresource Technol. 75 (2000) 